\title{
Distribution of ABO, Rhesus Factor Blood Phenotype and Haemoglobin Genotype among Antenatal Clinic Attendees in Anyigba, North Central Nigeria
}

\author{
Simon P. O. Akogu, Owemidu Idowu Olumorin and Shedrack Egbunu Akor
}

\section{ABSTRACT}

Background: In the practice of obstetrics and gynecology, the ABO and Rhesus factor (Rh) blood type are important. Blood typing for blood transfusion of compatible blood is very common in emergency and routine care. There is a scanty literature on the distribution of $\mathrm{ABO}$ and Rhesus blood types in Anyigba, (North central) Nigeria.

Objective: This study aims to determine the distribution of $\mathrm{ABO}$ blood and Rhesus blood group phenotypes and Hemoglobin genotypes among antenatal clinic attendees in a teaching hospital.

Methods: Antenatal records of attendees (October 2017 to September 2020) at the Kogi State University Teaching Hospital were retrieved and results of antenatal hematological investigations were collected using a structured tool.Bio data, ABO blood group, Rhesus group phenotype and Hemoglobin genotype were collected, inputted and analyzed using SPSS version 20.

Results: The mean age was $26+/-7$ years, blood group $O$ is most prevalent,561 (53.6\%) then A $276(26.4 \%)$, B $189(18.1 \%)$ and $A B, 21$ (2\%).1014 (96.4\%) were Rhesus D positive, 33 (3.1\%) were Rhesus D negative. For hemoglobin genotype, $786(75.1 \%)$ were AA, $258(24.6 \%)$ were AS, AC were $3(0.3 \%)$.

Conclusion: The distribution of the ABO, the Rhesus (D) blood groups and hemoglobin genotypes are in concurrence with the findings of previous studies; Blood group $O$ is the most prevalent and $A B$ the least prevalent, Rhesus (D) positive in the population is high and the hemoglobin genotype AA is the most prevalent. There is no association between blood group phenotypes studied and the hemoglobin genotypes.

Keywords: ABO, antenatal clinic, attendees, Anyigba, genotype, Nigeria, rhesus factor.

\section{INTRODUCTION}

The most frequently studied genetic markers in a large population of humans are $\mathrm{ABO}$ blood group and Rhesus factor antigens [1],[3],[4].

The most Immunogenetic red cell antigen discovered is the Rhesus blood groups while the ABO blood groups are the first notable red cell antigens. Their expressions are important as histo compatibility genes in blood transfusion and pregnancy. These expressions show variations across populations [4].

Anyigba town is in Dekina local government area in Kogi state, located between latitudes
Submitted : June 28, 2021

Published : November 8,2021

ISSN: 2593-8339

DOI: 10.24018/ejmed.2021.3.6.954

S. P. O. Akogu*

Department of Physiology/Obstetrics and Gynecology, Faculty of Basic Medical Sciences, College of Health Sciences, Kogi State University, Anyigba, Nigeria.

(e-mail:simon.a@ksu.edu.ng

O. I. Olumorin

Department of Physiology, Faculty of Basic Medical Sciences, College of Health Sciences, Kogi State University, Anyigba, Nigeria.

(e-mail: owemidu.io@ksu.edu.ng)

S. E. Akor

Department of Pathology, Faculty of Basic Clinical Sciences, College of Health Sciences, Kogi State University/ Kogi State University Teaching Hospital Anyigba, Nigeria.

(e-mail: shedrackegbunu@gmail.com)

*Corresponding Author $7^{\circ} 15^{\prime} \mathrm{N}-7^{\circ} 29^{\prime} \mathrm{N}$ and longitude $7^{\circ} 11^{\prime} \mathrm{E}-7^{\circ} 32 \mathrm{E}$. The town has an altitude of $385 \mathrm{~m}$ above sea level. It has an estimated population of 189,976 persons.

In clinical practice and especially in obstetrics and gynecological practice, the ABO blood and Rhesus factor (Rhesus blood type) and genotypes of individual are very important considerations in medical care, procreation, blood banking and transfusion. There is scanty literature on the distribution of $\mathrm{ABO}$ and Rhesus factor blood type and hemoglobin genotype in the Anyigba Population.

This study aims to determine the distribution of ABO blood groups and Rhesus blood phenotypes 
and Hemoglobin genotypes among antenatal clinic attendees at the Kogi state university teaching hospital in Anyigba, North central Nigeria. This will generate data and information for practitioners and blood transfusion managers to enhance clinical practice and management. Generated information will also enrich the data base of the scientific community.

\section{Materials And Methods}

Antenatal clinic records of attendees (October, 2017 to September, 2020) at the antenatal clinic of the Kogi state university teaching hospital were retrieved and reports of routine hematological assessment were collected using a structured questionnaire. The data collected included bio data, ABO blood group and Rhesus group phenotype and the hemoglobin genotype. These were inputted into SPSS 20 and analyzed. Prevalence was reported as absolute numbers and percentage of the studied population.

Ethical Clearance was obtained from the Research and Ethics committee of the Institution for this study.

\section{RESULTS}

The mean age of the studied population was 26 $+/-7$ years

Table I shows the ABO blood group distribution:275 (26\%) of them were blood group A, 189 (18.1\%) were blood group B, $21(2.0 \%)$ were blood group AB, while 561 (53.6\%) were blood group $\mathrm{O}$.

A total of $1014(96.4 \%)$ of the studied population were Rhesus D positive, while 33 (3.1\%) were Rhesus D negative as shown in Table II.

As shown in Table III, the prevalence of Rhesus antigen was highest in blood group O, 561 (53.6\%) and lowest in blood group AB 21(2\%).

The Hemoglobin genotypes distribution is shown in Table IV; $786\left(75.1^{\circ} \%\right)$ were AA, 258 $(24.5 \%)$ were AS, while AC were $3(0.3 \%)$. No SS genotype was seen in the studied population.

A correlation analysis shows that there is no significant association between a particular blood group and Rhesus factor phenotypes and hemoglobin genotype of the individual $(p=0.66)$.
TABLE I: ABO BLOOD GROUP PHENOTYPES AMONG ANTENATAL CLINIC ATTENDEES AT KOGI STATE UNIVERSITY TEACHING HOSPITAL ANYIGBA

\begin{tabular}{ccc}
\hline \hline Blood Groups & $\mathrm{N}$ & $\%$ \\
\hline \hline $\mathrm{A}$ & 276 & 26.4 \\
$\mathrm{~B}$ & 189 & 18.1 \\
$\mathrm{AB}$ & 21 & 2.0 \\
$\mathrm{O}$ & 561 & 53.6 \\
Total & 1047 & 100 \\
\hline \hline
\end{tabular}

TABLE II:RHESUS D FACTOR PHENOTYPES AMONG ANTENATAL CLINIC ATtendeEs AT Kogi State UnIVERsity TEACHING Hospital ANYIGBA

\begin{tabular}{ccc}
\hline \hline Rhesus D & $\mathrm{N}$ & $\%$ \\
\hline \hline Rh Positive & 1014 & 96.4 \\
Rh Negative & 33 & 3.1 \\
Total & 1047 & 100 \\
Total & 1047 & 100 \\
\hline \hline
\end{tabular}

TABLE III: RHESUS D PHENOTYPES IN THE ABO GROUPS AMONG ANTENATAL CLINIC ATTENDEES AT KOGI STATE UNIVERSITY TEACHING HOSPITAL ANYIGBA

\begin{tabular}{ccccccc}
\hline \hline $\begin{array}{c}\text { Blood } \\
\text { Group }\end{array}$ & $\mathrm{N}$ & $\%$ & $\begin{array}{c}\text { Rhesus } \\
\text { Positive }\end{array}$ & $\%$ & $\begin{array}{c}\text { Rhesus } \\
\text { Negative }\end{array}$ & $\%$ \\
\hline \hline A & 276 & 26.4 & 267 & 25.4 & 9 & 0.9 \\
B & 189 & 18.1 & 186 & 17.7 & 3 & 0.3 \\
AB & 21 & 2.0 & 21 & 2.0 & 0 & 0 \\
O & 561 & 53.6 & 540 & 51.3 & 21 & 2.0 \\
Total & 1047 & 100 & 1014 & 96.4 & 33 & 3.1 \\
\hline \hline
\end{tabular}

TABLE IV: DISTRIBUTION OF HEMOGLOBIN GENOTYPES AMONG ANTENATAL ANTENATAL CLINIC ATTENDEES AT KOGI STATE UNIVERSITY TEACHING HOSPITAL ANYIGBA

\begin{tabular}{ccc}
\hline \hline Genotypes & $\mathrm{N}$ & $\%$ \\
\hline \hline AA & 786 & 75.1 \\
AS & 258 & 24.6 \\
AC & 3 & 0.3 \\
Total & 1047 & 100 \\
\hline \hline
\end{tabular}

\section{Discussion}

In this present study, the blood group O (53.6\%) has the highest prevalence in the studied population. This finding is similar to the findings of [2], in the study of $\mathrm{ABO}$ and rhesus blood groups among blood donors in Kano, North Western Nigeria. It is also similar to the findings of [12] $(52.3 \%)$ and results from other parts of Nigeria like Jos (47.1\%) and Portharcout (56.3\%) [1],[13].

The next most prevalent blood group in this study is the blood group A (26.4\%) followed by B (18.1\%) and the least prevalent is $\mathrm{AB}(2 \%)$. These findings are in concurrence with previous studies with variation that may be accounted for by the sex and sample sizes of the participants in the studies [2],[5]-[8],[10].

The study showed that Rhesus (D) positivity in the population is $96.4 \%$. This is similar to the study of Jahapour et al [12] (97.7\%).However, Arwa et al found 89.3\% [12], [13],[14].

Rhesus D negative was found to have a low 
frequency of $3.2 \%$ which is close to that observed among the Yorubas (5.46\%) and also close to previous literature of $7.26 \%, 6.85 \%$ and 1.6\%.[4],[9], [12],[13],[14],[15].

These findings generally agree with previous work of [1] showing low Rhesus negativity among blacks in diaspora as compared to the $15 \%$ among the Caucasians.

In this study, the hemoglobin genotype AA is the most prevalent in the population $(75.1 \%)$. This is similar to the findings of [14] in Jos (73.9\%), [15] (75.7\%) and also within the range previously noted for the African population (50-75\%).

A test of association of the results of this study showed that there is no significant association between the ABO and Rhesus (D) blood groups and the hemoglobin genotypes. $(p=0.66)$. Reference [14] had similar findings in their study.

\section{Conclusion}

The distribution of the $\mathrm{ABO}$, the Rhesus (D) blood groups and hemoglobin genotypes are in concurrence with the findings of previous studies; Blood group $\mathrm{O}$ is the most prevalent and $\mathrm{AB}$ the least prevalent, there is high Rhesus (D) positivity in the population and the hemoglobin genotype AA is the most prevalent. There is no association between blood group phenotypes studied and the hemoglobin genotypes.

These findings justify further need for blood typing and proper documentation for antenatal care and patient management in general.

\section{REFERENCES}

[1] J. O. Ameand andO. Young, "A preliminary survey of the distribution of $\mathrm{ABO}$ and Rhesus blood groups in Trinidad,"Tropical and Geographical Medicine 7:375-8, 1955.

[2] O. K. Chima, T. B. Mohammed, K. Aisha, S. A. Alhaji, B. M. Muhammed andA. H. Kwaru, "ABO and Rhesus blood groups among blood donors in Kano, North-Western Nigeria,"Nigerian Journal of Basic Clinical Sciences 9:11-3, 2021.

[3] J. V. Dacie andS. M. Lewis, Practical hematology $9^{\text {th }}$ ed. London: Churchill Livingstone, Harcourt Publishers Limited, 2001.

[4] V. I. Iyawe, A. D. Igboroye andG. A. Akinyabi,"Preliminary survey of Rhesus inheritance and ABO blood groups in Nigerians," Nigerian Journal of Physiological Sciences 15:18-9, 1999.

[5] T. Korubo- Owiye andP. S. Igbigbi,"Distribution of ABO and Rhesus Genes among Socio- economic classes in port Harcourt, Nigeria,"Nigerian Journalof Physiological Sciences 10:22-8, 1994.

[6] A. G. Kulkumi, B. Peter,D. Z. Ibazedor and A. F. Fleming, "The $\mathrm{ABO}$ and Rhesus groups in the north of Nigeria,"Annals of TropicalMedicine Parasitology 79:83-8, 1984.

[7] E. E. Mathew and N. B. Godwin, "Distribution of ABO and Rhesus D blood groups in the Benin area of Niger Delta: Implications for regional blood transfusion,"Asian Journal of Transfusion Science 2:35,2008 .
[8] A. E. Mourant, A. C. Kopec and K. Donmainiewskisobezak,The distribution of blood groups and other polymorphisms $2^{\text {nd }}$ ed. London: Oxford University Press; 1968.

[9] G. O. Ojo,O. O. Ajose- Clokes and O. O. Balogun, "Frequency distribution of $\mathrm{ABO}$ and Rhesus blood groups in the Urban population of Lagos,"Nigerian Journal of Physiological Science 3:3:79-83, 1987.

[10] K. E. Onwukeme,"Blood group distribution in blood donors in a Nigerian population,"Nigeria Journal of Physiology Science 6:67-70, 1990.

[11] S. Worlledge,S. E. Ogiemudia, C. O. Thomas, B. N. Ikoku and L. Luzzutto,"Blood group antigens and antibodies in Nigeria,"Annals of TropicalMedicine Parasitology 86:249-64, 1974.

[12] O. Jahanpour, J. J. Pyuza, E. O. Ntiyakunze, A. Mremi and E. R. Shao, "ABO and Rhesus blood group distribution and frequency among blood donors at Kilimanjaro Christian Medical Center, Moshi, Tanzania," BMC Research Notes 10, 738, 2017.

[13] A. Z. Al-Riyami, A. Al-Marhoobi, S. Al-Hosni, S. Al Mahrooqi, M. Schmidt, S. O'brien and M. Al-Khabori, "Prevalence of red blood cell major blood group antigens and phenotypes among Omani blood donors," Oman Medical Journal 34(6): 496, 2019.

[14] M. D.Lungus,U.Y.Polit,O. U. Nnana, N. I. Vwandem and J. D. Damen, "Distribution of Hemoglobin Genotypes, ABO and Rhesus (D) blood groups among pregnant women in North Central Nigeria,"World Journal of pharmaceutical and Medical Research(wjpmr) 4(6): 54-58, 2018.

[15] A. A. Adeyemi, A. O. Ladipo, O. A. Omolade, D. D. Ogbaro, "Frequency Distribution of Hemoglobin Variants among Teenagers," British Journal of Medicine \& Medical Research 14(4): 1-5, 2016. 